\title{
POSITION AND DEVELOPMENT POTENTIAL OF NORTH-EASTERN BALTIC SEA REGIONS
}

\author{
Vladimír Žítek, Viktorie Klímová
}

Received: February 28, 2013

\begin{abstract}
ŽÍTEK VLADIMÍR, KLÍMOVÁ VIKTORIE: Position and development potential of north-eastern Baltic Sea regions. Acta Universitatis Agriculturae et Silviculturae Mendelianae Brunensis, 2013, LXI, No. 4, pp. 1203-1211

The article aims to compare the economic performance of north-eastern Baltic Sea regions with all 271 regions on the NUTS2 level in member states of the EU-27. The study is focused on Swedish, Finnish, Estonian, Lithuanian and Latvian regions. The evaluation is based on the synthesis of selected indicators. The article focuses on evaluating the present position of the regions in relation to the dynamics of their development. On this basis, it is possible to divide the regions in accordance with their economic development as well as their development trends into four categories: developed regions with a positive developmental trend, developed regions with a negative developmental trend, underdeveloped regions with a positive developmental trend and underdeveloped regions with a negative developmental trend. Consequently, the linking of the evaluation based on the synthesis of the above mentioned indicators with the values of regional GDP per capita has been carried out. As regards the evaluation of the relationship between the economic level of regions and the composite indicator, the calculations proved their close connection.
\end{abstract}

economic level, regional development, disparities, evaluation, composite indicator, NUTS 2 regions

\section{INTRODUCTION}

Among particular regions there are big differences in their socio-economic development. When evaluating the development of regions, we should take account of the region's development level in relation to the development level of other regions; in other words, the differences between particular regions. In economic theory, these differences are called regional disparities. The term "regional disparity" can be defined as differentness or inequality of characteristics, effects or processes that are clearly territorially located (Kutscherauer et al., 2008). The basic question that arises in this context is if regional disparities tend to increase or rather decrease. In other words, if there is a tendency towards convergence or rather divergence. However, for viewing the regional disparities, also the time period in which convergences or divergences arise is important. The convergent theories usually work with longer time periods that the divergent ones (Blažek, Uhliŕr, 2011). Besides the time point of view, the size of the disparities is important too. The existence of certain differences is desirable and necessary because it stimulates economic and social development. But enormous regional disparities have no stimulating effects and they have serious social and political consequences and so they are more often considered to be a negative phenomenon (Blažek, Uhlíř, 2011).

The European Union, especially its policy of economic and social cohesion, deals with the differences among regions as well. The article 174 of the Treaty on European Union says that "Union shall aim at reducing disparities between the levels of development of the various regions and the backwardness of the least favoured regions" (Treaty of Lisbon, 2007).

The EU cohesion policy is based on the division of regions in dependence on their gross domestic product. However, some opinions say that the GDP is not a sufficient indicator. For example, Ertur and Koch (2006) ascertained that the regional GDP 
depends on the GDP of neighbouring regions and that the regional development processes are also affected by spillover effects and spatial externalities. Therefore, the cohesion policy should also consider spatial interactions among regions. (With respect to the focus of this paper, we can note that spatial interactions are also obvious between Sweden and Finland on the one hand and Latvia, Lithuania and Estonia on the other hand.)

Economic development is closely related to the term competitiveness in market economies. Competitiveness serves as a basic measure of long-term success of companies, regions and states. One of the basic questions that arise when defining competitiveness is whether it is possible to speak about regional or national competitiveness or whether the term should only be used for companies. For example Krugman (1994) is wellknown for his rejection of national (regional) competitiveness. R. L. Martin (2004) speaks about microeconomic and macroeconomic views of competitiveness: the microeconomic approach is related to competitiveness of companies; the macroeconomic approach is related to competitiveness of states and regions. Nevertheless, both views are probably interrelated, because it can be claimed that competitiveness of individual firms (microeconomics) affects and determines the competitiveness of the economy as a whole (macroeconomics). Porter (e.g. 1998) prefers the term competitive advantage.

How should higher competitiveness be reached? Contemporary theories concerned with factors of competitiveness in developed countries connect their competitive advantage primarily with conditions for development of innovations in businesses. A higher level of innovations also brings a higher added value of products and therefore a higher growth of the living standard (Kučera, Pazour, 2009). Particularly in the last several decades, it has been widely acknowledged that regions are an important element in the transformation to the knowledge society and that they are also a significant driving force for economic growth based on research, technologies and innovations (Skokan, 2004).

For these reasons, innovation policy has demonstrated a new trend in the last decades and this is transfer of competences to the regional level. It is generally accepted that the location and spatial proximity are important for innovation development. The spatial proximity allows regions to create a unique competitive advantage achieved by e.g. tacit knowledge sharing, mutual formal and informal linkage of players and networking. The regionalization also functions as a natural opposite of globalization (Lundvall, 2010).

While the cohesion policy focuses primarily on reducing the regional disparities (mainly through the support of infrastructure, innovations and knowledge society), the policy of research, development and innovations focuses on creating the conditions that can help regions to achieve the knowledge economics. When implementing an innovation policy, it is necessary to bear in mind that each region is specific and different from the others. If we wish an efficient and effective innovation policy, it should be adapted to specific features of individual regions (e.g. Tödtling, Trippl, 2005; Bristow, 2010).

The increase in employment and competitiveness is also closely connected with 'high-tech sector'. High-tech sector is considered to be the key factor for the economic and productivity growth. The indicators of technology and knowledge-intensive sectors are used not only for the evaluation of the competitiveness of states and regions but also for the evaluation of the utilization of research and development results (or rather the utilization of new knowledge).

Currently, a number of studies are published that evaluate competitiveness and innovation performance at national and regional levels. The best-known evaluations of competitiveness of countries are the Global Competitiveness Index published annually by the World Economic Forum and the World Competitiveness Scoreboard provided annually by the Institute for Management Development. Also the evaluation of innovation performance called Innovation Union Scoreboard is well established. This assesses mainly EU countries every year (European Commission, 2012). The evaluation in 2006, which is the period to which the evaluation of north-eastern Baltic Sea regions explored in the following chapters is related, showed that as regards these countries, Finland and Sweden are in the group of innovation leaders, Estonia is slightly below the EU average and Lithuania and Latvia are countries with a low innovation activity Tarantola et al. (2007).

The innovation performance of EU regions is assessed within the Regional Innovation Scoreboard. The methodology of this assessment is based on the study Innovation Union Scoreboard but is slightly modified for the reason of unavailability of some data at regional level. Tab. I shows the innovation performance of NUTS 2 regions we explore in this paper.

However, there are studies that evaluate competitiveness and innovation performance within a territory of one state. Probably the bestknown of them is the UK Competitiveness Index (Huggins, 2003 or Huggins, Thomson, 2010). Let us concentrate on the studies concerning the countries explored in this paper. Vilnius, Klaipeda and Kaunas were identified as the most competitive NUTS3 regions in Lithuania (Snieška, Bruneckiené, 2009). The same study also proved that the GDP indicator cannot truly indicate the regional competitiveness and that more indicators have to be combined. Lankhuizen (2000) explains the low competitiveness of Lithuania, Latvia and Estonia by their socialist past, which separated research and development from production. In his 
I: Regional innovation performance of north-eastern Baltic Sea regions (2006)

\begin{tabular}{|c|c|c|c|}
\hline \multicolumn{2}{|r|}{ Region } & \multirow{2}{*}{$\begin{array}{c}\text { Innovation index (a) } \\
0.90\end{array}$} & \multirow{2}{*}{$\begin{array}{c}\text { Innovation group (b) } \\
\text { high innovator }\end{array}$} \\
\hline SEl1 & Stockholm & & \\
\hline SE23 & Västverige & 0.83 & high innovator \\
\hline SE22 & Sydsverige & 0.76 & high innovator \\
\hline SE12 & Östra Mellansverige & 0.74 & high innovator \\
\hline FI19 & Länsi-Suomi & 0.65 & high innovator \\
\hline SE31 & Norra Mellansverige & 0.57 & medium-high innovator \\
\hline SE33 & Övre Norrland & 0.57 & medium-high innovator \\
\hline SE21 & Småland med öarna & 0.54 & medium-high innovator \\
\hline EEO0 & Estonia & 0.38 & average innovator \\
\hline LTO0 & Lithuania & 0.33 & medium-low innovator \\
\hline LV00 & Latvia & 0.32 & low innovator \\
\hline FI20 & Åland & n.a. & n.a. \\
\hline
\end{tabular}

Source: Tarantola et al. (2007), (a); Hollanders et al. (2009) (b)

opinion, this is the reason why these countries are only competitive in sectors with low technological intensity and he considers this fact the main barrier to their technological progress. The importance of cooperation between particular agents of the innovation system was also confirmed by a Finnish study (Autio, Yli-Renko, 1998). The study proved that small innovation companies from hi-tech fields grow faster than small companies in low-tech. Hitech companies are more involved in innovation networks, cooperate with universities and research institutes and supply to large companies. The relationship between political stability and economic growth in Baltic states (Estonia, Lithuania and Latvia) was analysed by Grochova and Kouba (2011) and they say that the case of the Baltic states positively shows that countries can grow very fast even in the environment of significant elite political instability.

\section{METHODOLOGY OF EVALUATION}

The aim of this article is to compare the economic performance of north-eastern Baltic Sea regions with all 271 regions on the NUTS 2 level in member states of the EU (EU-27). Baltic Sea countries, specifically Estonia, Latvia, Lithuania, Finland and Sweden, were chosen for this research for several reasons. First of all, they are geographically close and have similar natural and climatic conditions; at the same time, these countries experienced a very different economic and social development during the $20^{\text {th }}$ century. This is demonstrated not only by their differing economic performance but also a different position of these countries in the evaluation of innovation performance, which is a prerequisite for further development. Therefore, it is interesting to see what the position of post-
Soviet states is (these are not divided at NUTS2 level) in comparison with regions of Finland and Sweden and whether their situation is improving or not. For similar comparisons, the indicator of gross domestic product (per capita) is usually used, alternatively this indicator can be complemented by other characteristics. The evaluation presented in this study is based on the synthesis of selected available indicators (excluding GDP) which can be considered the key prerequisites for or aspects of the economic level of the regions and which according to authors emphasize the principles of knowledge economy. (Therefore the indicators have qualitative dimension to a considerable extent.) The source of the data is Eurostat (Eurostat, 2010a).The selected indicators are the following:

- disposable household income

- unemployment rate

- expenditures on research and development

- employment in research and development

- employment in knowledge-intensive services

- employmentin high and medium high-technology manufacturing sector.

These selected indicators can be characterized in this way:

- Expenditures on research and development

This indicator expresses the total annual expenditures on research and development as a percentage of the gross domestic product (GERD). The expenditures include expenditures of the government, businesses, higher education institutions and private non-profit organizations.

- Employment in research and development

The indicator expresses the percentage of the employees in research and development vis-à-vis the total employment. Such employees include 
both researchers themselves and other employees (technical and economic staff and others) of research institutions.

- Employment in knowledge-intensive services

The indicator of the employment in knowledgeintensive services expresses the proportion of employment in these fields to the total employment. The NACE (rev. 1.1) fields which are among the knowledge-intensive services are fields with codes $61,62,64,65,66,67,70,71,72,73,74,80,85$ and 92 (Eurostat, 2010b).

- Employment in high and medium-high technology manufacturing sector

The data shows the employment in high and medium-high technology manufacturing sectors as a share of total employment. The NACE (rev. 1.1) fields which are among the high or medium-high technology manufacturing sectors are fields with codes 30, 32, 33 or 24, 29, 31, 34, and 35 (Eurostat, 2010b).

- Unemployment rate

The International Labour Organization (and the Eurostat methodology (Eurostat, 2007)) defines an unemployed worker as someone who is older than 15, actively seeking work and able to start a job immediately or within 14 days. The unemployment rate is generally the most available indicator, as it is followed closely by all member states. Its static values, and their changes, are interesting not only for research but they are also important for the implementation of an economic policy.

- Disposable household income

Eurostat statistics differentiate between two kinds of income - the primary and the disposable income. The disposable income was chosen for the analysis as it more suitably expresses the real purchasing power of the population. The disposable income includes all incomes after taxation and deduction of insurance fees, further it includes accepted social transfers (Behrens, 2003).

We considered adding several other indicators to this analysis (e.g. households with access to the internet at home or students in tertiary education); these are usually considered prerequisites for future development of a region. However, these indicators had to be excluded in the end because of nonavailability of needed data in all regions.

The above mentioned indicators have been included in the evaluation. Within the framework of the analysis, values of each indicator have been divided into five groups (highly above-average, above-average, average, below-average, highly below-average). These groups were assigned with ranking 1-5: the higher (for unemployment the lower) value of indicator, the lower ranking (i.e. highly above-average $=1$, highly below-average $=5$ ) . Consequently, the synthesis has been carried out. The value of the composite indicator of the j-region $\left(E_{j}\right)$ is determined according to this formula:

$$
E_{j}=\frac{\sum_{i=1}^{6} w_{i} \times F_{i}}{\sum_{i=1}^{6} w_{i}},
$$

where $\mathrm{w}_{\mathrm{i}}$ is weight of the i-indicator (the weight of each indicator was established to be 1 ) and $F_{i}$ is value of the i-indicator (1-5).

The evaluation is carried out both as static, when data for 2006 were used, and dynamic, when the change (index) between 2000 and 2006 is calculated. On this basis, it is possible to divide the regions in accordance with their economic development as well as their development trends.

Another important contribution of this article is the linking of the evaluation based on the synthesis of the above mentioned indicators with the values of regional GDP per capita. Besides the elementary calculation of the correlation coefficient, it is possible to present the relation of the composite indicator (that which is - as has been said above based on the qualitative characteristics compatible with knowledge economics) to the economic performance expressed through GDP per capita. Therefore, the regions can be divided according to their economic performance as well as the core of its essence. For the purpose of this comparison, all values of indicators on the level NUTS 2 were expressed as percentages of the EU27 average value (see part 3.1). Subsequently, the composite indicator $E_{j}$ is calculated for each region NUTS2 (in \%), where $\mathrm{F}_{\mathrm{i}}$ is the value of the i-indicator in \% (see part 3.2).

Special attention is paid to north-eastern Baltic Sea regions, both new member states of the EU (Estonia, Latvia, Lithuania) and Finnish and Swedish regions, i.e. countries with developed market economies that fall within EU-15. In the days when the analyses whose results are presented in this article were compiled neither Estonia (EE00), Latvia (LV00) nor Lithuania (LTO0) were subdivided into level NUTS2 and so each of the states consists of one unit. Finland was divided into 5 units (FI13: ItäSuomi, FI18: Etelä-Suomi, FI19: Länsi-Suomi, FIla: Pohjois-Suomi, FI20: Åland) and Sweden into 8 units (SE11: Stockholm, SE12: Östra Mellansverige, SE21: Småland med öarna, SE22: Sydsverige, SE23: Västverige, SE31: Norra Mellansverige, SE32: Mellersta Norrland, SE33: Övre Norrland). The geographical position of the mentioned regions is demonstrated in Fig. 1.

\section{RESULTS}

In accordance with the methodology, the data for all NUTS2 regions in the EU27 have been found out. After calculating this indicator for each region, it was possible to compare:

- the position of the individual regions in the context of the static values of the composite indicator (2006) and the dynamic values (change between 2006 and 2000), 


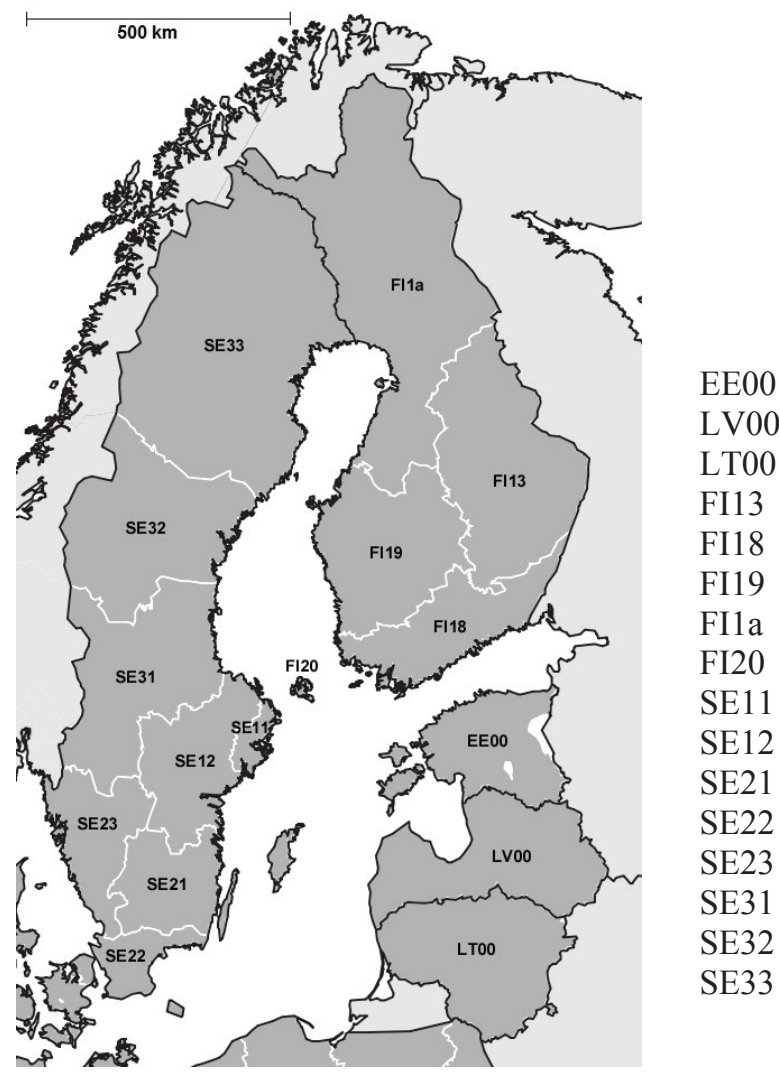

1: Map of north-eastern Baltic Sea regions Source: authors

$\begin{array}{ll}\text { EE00 } & \text { Estonia } \\ \text { LV00 } & \text { Latvia } \\ \text { LT00 } & \text { Lithuania } \\ \text { FI13 } & \text { Itä-Suomi } \\ \text { FI18 } & \text { Etelä-Suomi } \\ \text { FI19 } & \text { Länsi-Suomi } \\ \text { FI1a } & \text { Pohjois-Suomi } \\ \text { FI20 } & \text { Åland } \\ \text { SE11 } & \text { Stockholm } \\ \text { SE12 } & \text { Östra Mellansverige } \\ \text { SE21 } & \text { Småland med öarna } \\ \text { SE22 } & \text { Sydsverige } \\ \text { SE23 } & \text { Västverige } \\ \text { SE31 } & \text { Norra Mellansverige } \\ \text { SE32 } & \text { Mellersta Norrland } \\ \text { SE33 } & \text { Övre Norrland }\end{array}$

- the relationship between the values of the composite indicator and regional GDP (both of them were used as a percentage of EU27 average in 2006).

\section{I Static and dynamic value of the composite indicator of the economic level of the regions}

On the basis of the above mentioned comparison, it is possible to divide the regions into four categories according to their situation (see Fig. 2):

- developed regions with a positive developmental trend (the value of the static indicator is between 1.0 and 3.0, the value of the dynamic indicator is between 1.0 and 3.0) - 60 regions,

- developed regions with a negative developmental trend (the value of the static indicator is between 1.0 and 3.0, the value of the dynamic indicator is between 3.1 and 5.0) - 56 regions,

- underdeveloped regions with a positive developmental trend (the value of the static indicator is between 3.1 and 5.0, the value of the dynamic indicator is between 1.0 and 3.0) - 106 regions,

- underdeveloped regions with a negative developmental trend (the value of the static indicator is between 3.1 and 5.0, the value of the dynamic indicator is between 3.1 and 5.0) - 37 regions.
In Figure 3 it is also possible to see the position of the examined Baltic Sea regions. Three Finnish and four Swedish regions were placed into the first group of developed regions with a positive developmental trend, regions FI18: Etelä-Suomi, SE33: Övre Norrland and SE32: Mellersta Norrland reached the boundary dynamic value 3.0.

Three Swedish regions SE23: Västverige, SE12: Östra Mellansverige, SE1l: Stockholm were placed into the second group of developed regions with a negative developmental trend.

Latvia (LVO0) and Estonia (EE00) do well in the group of underdeveloped regions with a positive developmental trend, the value of the dynamic indicator being 1.7 and 2.0, respectively. These regions are followed by Lithuania (LTO0). In addition to them also FI13: Itä-Suomi and SE31: Norra Mellansverige were placed into this group.

From all examined Baltic Sea regions only island FI20: Åland was classified as an underdeveloped region with a negative developmental trend.

From a broad point of view, considering the ascertained position of Baltic Sea regions, it is possible to state that developed Swedish and Finnish regions have either slightly positive or slightly negative developmental trend, whereas the trio of the new member states has the highest dynamics of development in the examined area. 


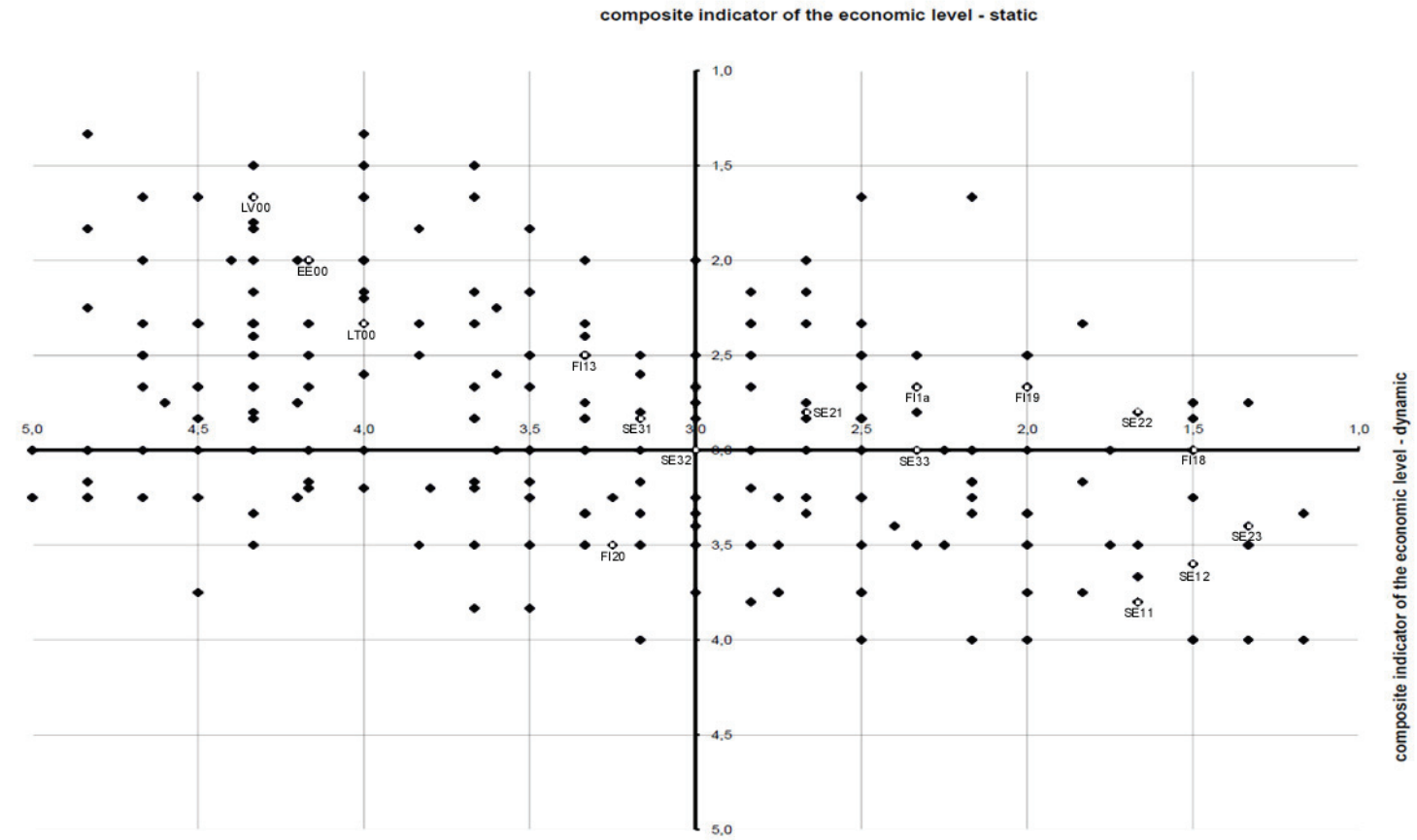

2: Static (2006) and dynamic (change between 2006 and 2000) value of the composite indicator of the economic level of the regions Source: Eurostat (data), the authors' research (methodology and calculation)

\subsection{The relationship between the values of the composite indicator and regional GDP}

The correlation analysis confirmed quite a close connection between these two indicators. The correlation coefficient for all regions is 0.73, after elimination of two regions with extreme values (Inner London and Luxembourg) it is even 0.78.

On the basis of the comparison, it is possible to divide the regions into four categories according to the essence of their economic level (see figure 3):

- developed regions with characteristics compatible with knowledge economics (GDP > 100\% and dynamic indicator also > 100\%) - 115 regions,

- developed regions without characteristics compatible with knowledge economics (GDP > 100\% and dynamic indicator < 100\%) 28 regions,

- underdeveloped regions with characteristics compatible with knowledge economics (GDP < 100\% and dynamic indicator > 100\%) 10 regions,

- underdeveloped regions without characteristics compatible with knowledge economics (GDP $<100 \%$ and dynamic indicator also $<100 \%$ ) - 114 regions.

A high correlation rate between GDP and the composite indicator of the economic level has also appeared in the classification of European regions into individual groups where it is clearly proved that developed regions usually have parameters of the knowledge economics (115 units) whereas less developed do not (114 units).

This general tendency also appears among Baltic Sea regions where 6 Swedish (SE1l: Stockholm,
SE23: Västverige, SE33: Övre Norrland, SE21: Småland med öarna, SE22: Sydsverige, SE12: Östra Mellansverige) and 3 Finnish (FI18: Etelä-Suomi, FI19: Länsi-Suomi, FIla: Pohjois-Suomi) NUTS2 regions fall within the group of developed regions with parameters compatible with knowledge economics. On the contrary, the three new member states of the EU (Estonia, Latvia, Lithuania) and Finnish region FI13: Itä-Suomi (with boundary values of both indicators) fall within the group of regions with opposite parameters.

The remaining three Baltic Sea regions (FI20: Åland, SE32: Mellersta Norrland and SE31: Norra Mellansverige) are different from this point of view, we can find them in the group of developed regions without parameters compatible with knowledge economics.

\section{CONCLUSIONS}

Economic and social disparities between regions are natural. The European cohesion policy as well as regional policies of particular states have attempted to eliminate them; however, disparities cannot be removed and it is not even desirable. Disparities of regions are closely related to regional competitiveness.

Recently, there have been efforts to express competitiveness and innovation performance of states and regions with numbers and compare them. From this point of view, countries of northern Europe, especially Sweden and Finland, are very successful and the other countries see them as their models. Innovation performance of the other north-eastern Baltic Sea countries (especially Latvia 


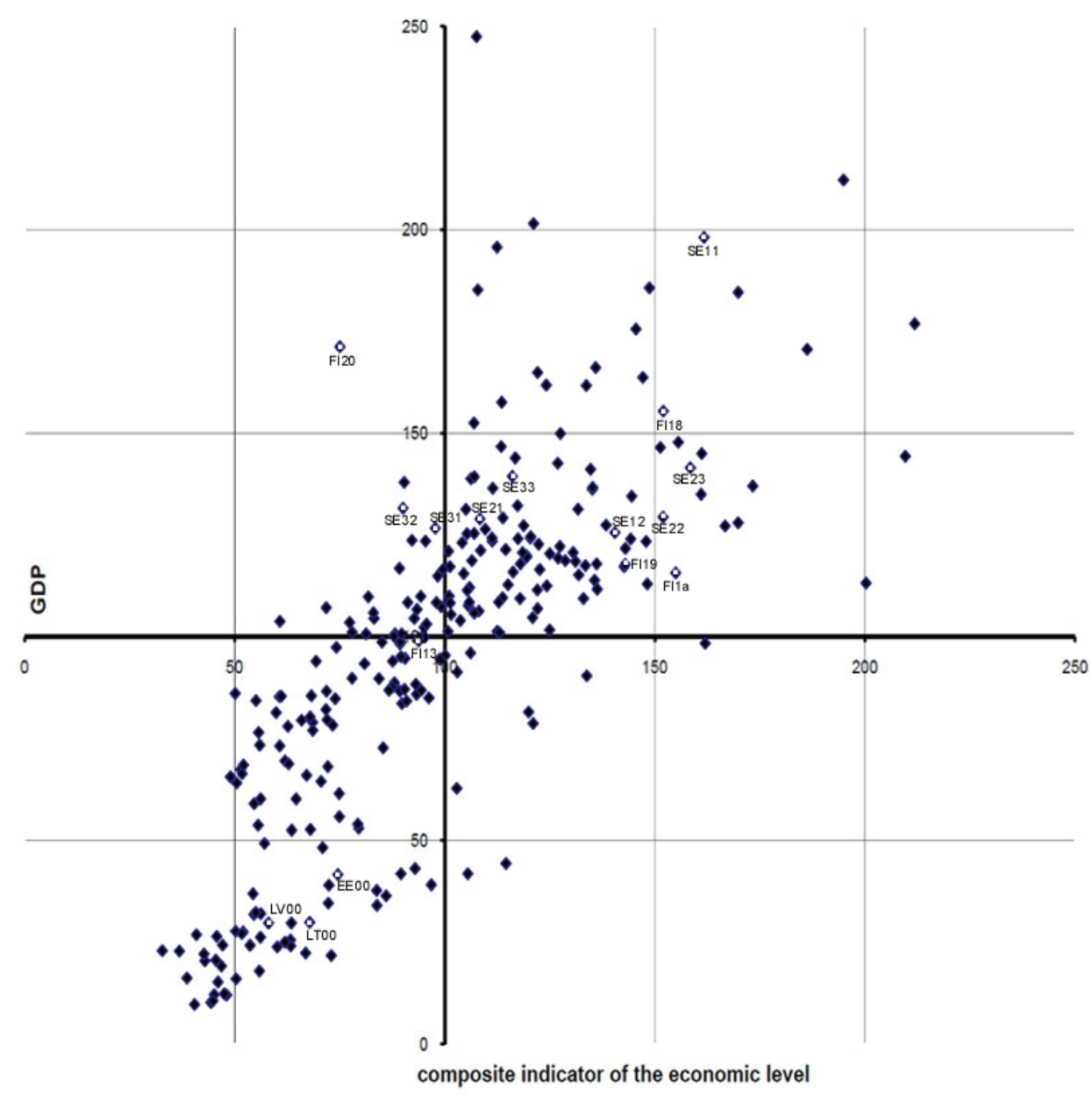

3: The relationship between the values of the composite indicator and regional GDP (2006)

Note: For better lucidity, the regions of Inner London (129.4\%, 382.9\%) and Luxembourg (125.4\%, $305.6 \%)$ were removed from the figure.

Source: Eurostat (data), authors' research (methodology and calculation)

and Lithuania) is very low, which can be explained by their different historical development. The geographical proximity and narrow cooperation with Sweden and Finland could be the sources of their economic growth and better innovation performance.

The presented study confirmed the anticipated existence of considerable differences in the economic level of NUTS2 regions, from the perspective of both their maturity measured by the composite indicator and GDP. It was proved that some regions are in the situation which cannot be called positive from the perspective of the composite indicator. These include Latvia (LV00) with an indicator value of 4.0, Estonia (EEO0) with a value of 4.2 and Lithuania (LTOO) with a value of 4.3. At the same time, it is possible to say that some of them have the right developmental trend, which is also valid for Latvia, which is the most successful of the examined Baltic Sea regions with its value of dynamic indicator 1.7, but also Estonia and Lithuania. Even these two Baltic Sea countries reach a higher value of the dynamic version of the synthetic indicator than Finland and Sweden. To sum up the main results, the position of the new EU member states is worse than position of Finland and Sweden, but important is the higher positive developmental trend of the three Baltic countries. Although the trend is positive, we have to perceive the convergence of the regions as a longterm matter. Furthermore, there is little probability that the three Baltic states will approach the most developed regions in Sweden and Finland. It seems more probable to approach to regions like PohjoisSuomi (FIla) or Länsi-Suomi (FI19).

As regards the evaluation of the relationship between the economic level of regions (expressed by GDP) and the composite indicator (characteristics of knowledge economics), the calculations proved their close connection. This also appeared in the position of the developed Swedish and Finnish regions on the one side and the new member states Estonia, Latvia and Lithuania on the other side. Upon closer examination, the results show that a special position is held by the regions that represent cores of the two innovation leaders of European countries, which 
at the same time represent developed knowledge economies.

Region SE11, which consists of the capital of Sweden, Stockholm, and its wider surroundings, has a very special position (GDP approaches $200 \%$ of the average, the synthetic indicator of economic level exceeds $160 \%$ of the average). Other excellent regions follow - FI18: Etelä-Suomi, SE23: Västverige, and SE22: Sydsverige. Region FI18: Etelä-Suomi includes not only the capital of Finland, Helsinki, but also other economic centres such as Espoo (the second largest city in Finland) and Turku. Region SE23: Västverige represents the western part of Swedish economy, where the main economic activities concentrate in the second largest city Göteborg, which is the key development pole of this area. Region SE22: Sydsverige contains centres of supernational (Malmö) and superregional (Helsingborg, Lund) significance.

These regions are strong competitors with evaluations of similar character. At the same time, they are significant potential sources of inspiration, partnership and cooperation for Baltic republics; using them, they could abandon the bad positions they are holding within European economy and approach the developed regions of Finland and Sweden soon.

\section{SUMMARY}

Among particular regions, there are big differences in their socio-economic development and these differences are called regional disparities. The aim of the article is to compare the economic performance of north-eastern Baltic Sea regions (regions in Estonia, Latvia, Lithuania, Finland and Sweden) with all 271 regions on the NUTS 2 level in member states of the EU. These Baltic Sea countries are geographically close and have similar natural and climatic conditions. At the same time, these countries experienced a very different economic and social development during the 20th century. The evaluation presented in this study is based on the synthesis of selected available indicators which can be considered the key prerequisites for or aspects of the economic level of the regions: disposable household income, unemployment rate, expenditures on research and development, employment in research and development, employment in knowledgeintensive services, and employment in high and medium high-technology manufacturing sector. Within the framework of the analysis, values of each indicator have been divided into five groups (highly aboveaverage, above-average, average, below-average, highly below-average). Consequently, the synthesis has been carried out. The evaluation is carried out both as static, when data for 2006 were used, and dynamic, when the change (index) between 2000 and 2006 is calculated. On this basis, it is possible to divide the regions in accordance with their economic development as well as their development trends into four categories: developed regions with a positive developmental trend (three Finnish and four Swedish regions), developed regions with a negative developmental trend (3 Swedish regions), underdeveloped regions with a positive developmental trend (Latvia, Estonia, Lithuania, one Finnish and one Swedish region) and underdeveloped regions with a negative developmental trend (one Finnish region). Another important contribution of this article is the linking of the evaluation based on the synthesis of the above mentioned indicators with the values of regional GDP per capita. On the basis of the comparison, it is possible to divide the regions into four categories according to the essence of their economic level: developed regions with (or without) characteristics compatible with knowledge economics and underdeveloped regions with (or without) characteristics compatible with knowledge economics.

\section{REFERENCES}

AUTIO, E., YLI-RENKO, H., 1998: New, technologybased firms in small open economies - An analysis based on the Finnish experience. Research Policy, 26, 9: 973-987. ISSN 0048-7333. DOI: 10.1016/ S0048-7333(97)00054-1.

BEHRENS, A., 2003: Income of private households and gross domestic product in Europe's regions. Statistics in focus, General statistics. Theme 1-7/2003. ISSN 1561-4875.

BLAŽEK, J., UHLÍŘ, D., 2011: Teorie regionálního rozvoje: nástin, kritika, implikace. 2. vyd., přeprac. a rozš. v. Praha: Karolinum, 342 s. ISBN 978-80246-1974-3.
BRISTOW, G., 2010: Critical reflections on regional competitiveness: theory, policy and practice. London: Routledge Studies in Human Geography, 186 p. ISBN 978-0-415-47159-6.

ERTUR, C., KOCH, W., 2006: Regional Disparities in the European Union and the Enlargement Process: An Exploratory Spatial Data Analysis 1995-2000. The Annals of Regional Science, 40, 4: 723-765. ISSN 0570-1864. DOI: 10.1007/s00168-006-0062-x.

European Commission, 2012: Innovation Union Scoreboard. Available at www.proinno-europe.eu. Eurostat, 2007: Eurostat regional yearbook 2007. Luxembourg: Office for Official Publications of the European Communities. ISSN 1681-9306. 
Eurostat, 2010a: Regions and cities statistics. Available at http://epp.eurostat.ec.europa.eu/portal/page/ portal/region_cities/introduction.

Eurostat, 2010b: High-tech industry and knowledgeintensive services. Reference Metadata in Euro SDMX Metadata Structure (ESMS). Available at http:// ec.europa.eu/eurostat.

GROCHOVÁ, L., KOUBA, L., 2011: Political instability and economic growth: an empirical evidence from the Baltic states. Acta univ. agric. et silvic. Mendel. Brun., 59, 2: 81-88. ISSN 1211-8516.

HOLLANDERS, H., TARANTOLA, S., ALEXANDER LOSCHKY, A., 2009: Regional Innovation Scoreboard (RIS) 2009. Available at http://ec.europa.eu/ enterprise/policies/innovation/files/ris-2009_ en.pdf.

HUGGINS, R., 2003: Creating a UK Competitiveness Index: Regional and Local Benchmarking. Regional Studies, 37, 1: 89-96. ISSN 0034-3404. DOI: 10.1080/0034340022000033420.

HUGGINS, R., THOMPSON, P., 2010: UK Competitiveness Index 2010. Cardiff: University of Wales Institute, 44 p. ISBN 1-902829-07-7.

KRUGMAN, P., 1994: Competitiveness: A Dangerous Obsession. Foreign Affairs, 73, 2: 28-44. ISSN 00157120. DOI: $10.2307 / 20045917$.

KUČERA, Z., PAZOUR, M., 2009: Srovnání národních inovačních systémů vybraných evropských zemí. ERGO. 4, 2: 3-9. ISSN $1802-$ 2170.

KUTSCHERAUER, A., HUČKA, M., SKOKAN, K. A KOL., 2008: Teorie, identifikace, klasifikace a hodnocení regionálních disparit. Prüběžná výzkumná zpráva. Ostrava:VŠB-Technická univerzita Ostrava.

LANKHUIZEN, M., 2000: Shifts in foreign trade, competitiveness and growth potential: from Baltics to 'Bal-techs'? Research Policy, 29, 1: 9-29. ISSN 0048-7333. DOI: 10.1016/S0048-7333(99)00034-7.
LUNDVALL, B. A., 2010: National systems of innovation: towards a theory of innovation and interactive learning. London: Anthem Press, 388 p. ISBN 9781843318668.

MARTIN, R. L., 2004: A Study on the Factors of Regional Competitiveness. A draft final report for The European Commission Directorate-General Regional Policy. Available at http://ec.europa. eu/regional_policy/sources/docgener/studies/ pdf/3cr/competitiveness.pdf.

PORTER, M. E., 1998: The competitive advantage of nations. New York: Free Press, 855 p. ISBN 0684841479.

SKOKAN, K., 2004: Konkurenceschopnost, inovace a klastry v regionálním rozvoji. Ostrava: Repronis, 159 s. ISBN 80-7329-059-6.

SNIEŠKA, V., BRUNECKIENÉ, J., 2009: Measurement of Lithuanian Regions by Regional Competitiveness Index. Engineering Economis, 61, 1: 45-57. ISSN 1392-2785.

TARANTOLA, S., GATELLI, D., HOLLANDERS, H., 2007 : European Innovation Scoreboard 2006 Comparative Analysis of Innovation. Luxembourg: Office for Official Publications of the European Communities. Available at http:// publications.jrc.ec.europa.eu/repository/ bitstream/111111111/8629/1/reqno_jrc36794_ final\%5B2\%5D.pdf.

TÖDTLING, F. TRIPPL, M., 2005: One size fits all? Towards a differentiated regionalinnovation policy approach. Research Policy, 34, 8: 1203-1219. ISSN 0048-7333. DOI: 10.1016/j.respol.2005.01.018.

Treaty of Lisbon, 2007: Amending the Treaty on European Union and the Treaty establishing the European Community. Official Journal of the European Union (2007/C 306/01). Available at http://eur-lex.europa.eu/LexUriServ/LexUriServ. do?uri=OJ:C:2007:306:FULL:EN:PDF.

Address

Ing. Vladimír Žítek, Ph.D., Ing. Viktorie Klímová, Ph.D., Department of Regional Economics and Administration, Faculty of Economics and Administration, Masaryk University, Lipová 4la, 60200 Brno, Czech Republic, e-mail: zitek@econ.muni.cz, klimova@econ.muni.cz 